\title{
Tamarisk...Maybe Not Invincible
}

\author{
Lee E. Hughes
}

Tamarisk (Tamarix ramosissima Ledeb.) is one cussed bush. Cussed because it's a heavy water user, not great wildife habitat, hard to hike through, and an exotic.

Much effort is taking place to find final solutions to its dominance in the Virgin and Colorado River Basins (Arizona, Nevada, and Utah). There are planning efforts to develop basin wide thinning or eradication of tamarisk (Virgin River Basin Tamarisk Work Group Draft Mission Statement). Biological controls are being developed to thin out the tamarisk population (Deloach 1997). Department of the Interior agencies have had some success in eradicating it in small areas, such as springs by using mechanical and chemi- cal methods. The National Park Service((NPS) has put forth a year-toyear effort in some springs and other small water sources to eradicate tamarisk in the Glen Canyon and Lake Mead National Recreation Areas(Nancy Brian, National Park Service, Personal Communication).

Like a lot of efforts, different strategies emerge depending on the individuals and the areas involved. There are the headon-frontal-attack-of-the-species strategies to the minimalist strategies. Both have their places depending on the money available and time tables of those involved.

In the early 1990s, the Arizona Strip Field Office of the Bureau of Land Management began inventorying its riparian resources. Another and more extensive inventory on the Virgin River took place in Utah, Arizona and Nevada in the mid-1990s. During these efforts monitoring sites were established on the Virgin and Paria Rivers and Kanab Creek, to determine the trends of the various woody species growing on the regeneration zone along these rivers. As

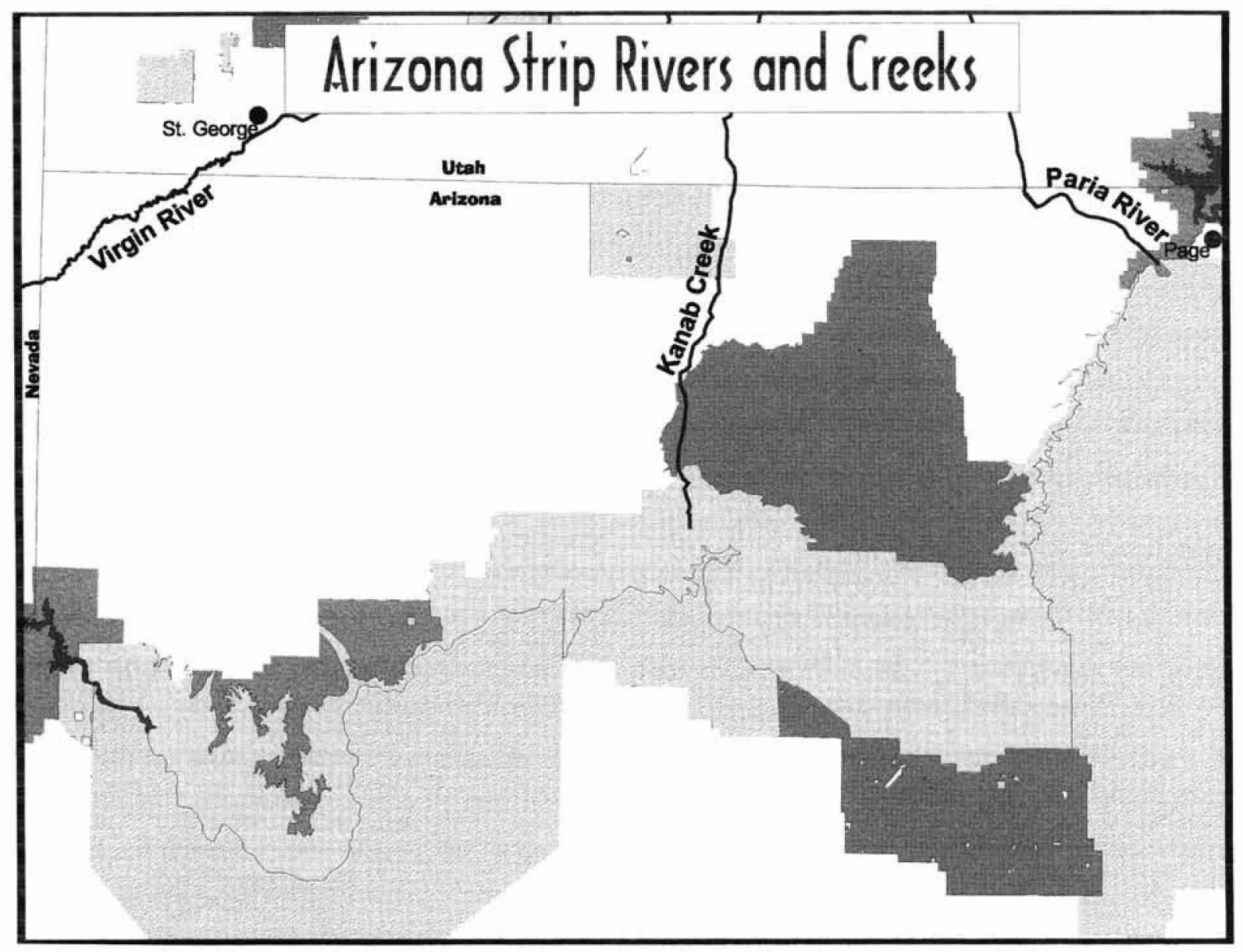


TABLE 1

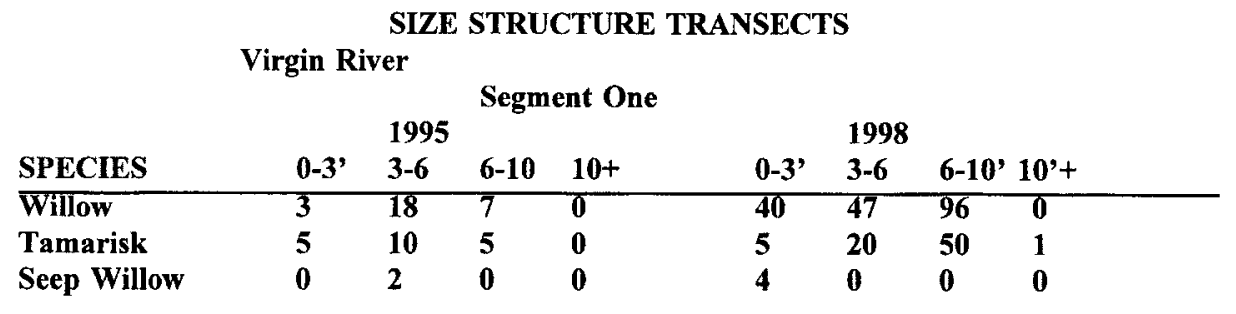

\section{Segment Seven}

$\begin{array}{lllllllll}\text { Willow } & 15 & 48 & 39 & 0 & 139 & 196 & 279 & 0 \\ \text { Tamarisk } & 7 & 6 & 9 & 0 & 19 & 45 & 51 & 0 \\ \text { Seep Willow } & 0 & 7 & 1 & 0 & 10 & 4 & 11 & 0\end{array}$

Segment Nine

$\begin{array}{lllllllll}\text { Willow } & 7 & 36 & 15 & 0 & 10 & 9 & 14 & 0 \\ \text { Tamarisk } & 23 & 24 & 18 & 0 & 3 & 2 & 15 & 0 \\ \text { Seep Willow } & 6 & 8 & 0 & 0 & 0 & 1 & 1 & 0 \\ \text { Arrowweed } & 3 & 9 & 0 & 0 & 19 & 103 & 0 & 0\end{array}$

\begin{tabular}{|c|c|c|c|c|c|c|c|c|}
\hline \multicolumn{9}{|c|}{$\begin{array}{l}\text { Kanab Creek } \\
\text { Segment } 3\end{array}$} \\
\hline \multicolumn{7}{|c|}{1995} & \multicolumn{2}{|c|}{1997} \\
\hline Willow & 7 & 9 & 16 & 14 & 13 & 60 & 202 & 9 \\
\hline Gooding Willow & 0 & 0 & 0 & 2 & 0 & $\mathbf{0}$ & $\mathbf{0}$ & $\mathbf{0}$ \\
\hline Tamarisk & 2 & 2 & 1 & 9 & 0 & 1 & 0 & $\mathbf{0}$ \\
\hline Seepwillow & $\overline{1}$ & 6 & 2 & 0 & 2 & 4 & 0 & $\mathbf{0}$ \\
\hline
\end{tabular}

\begin{tabular}{lcclllllll}
\multicolumn{3}{c}{ Paria River } & \multicolumn{1}{c}{} & & & & & \\
Arrowweed & $\mathbf{8 9}$ & $\mathbf{0}$ & $\mathbf{0}$ & $\mathbf{0}$ & $\mathbf{5 1}$ & $\mathbf{1}$ & $\mathbf{0}$ & $\mathbf{0}$ \\
Rabbitbrush & 7 & $\mathbf{0}$ & $\mathbf{0}$ & $\mathbf{0}$ & $\mathbf{2 8}$ & $\mathbf{3}$ & $\mathbf{0}$ & $\mathbf{0}$ \\
Cottonwood & $\mathbf{2}$ & $\mathbf{0}$ & $\mathbf{1}$ & $\mathbf{1}$ & $\mathbf{5}$ & $\mathbf{2}$ & $\mathbf{0}$ & $\mathbf{4}$ \\
Russian Olive & 4 & $\mathbf{3}$ & $\mathbf{4}$ & $\mathbf{3}$ & $\mathbf{5}$ & $\mathbf{3}$ & $\mathbf{1 3}$ & $\mathbf{5}$ \\
Seep Willow & $\mathbf{6 2}$ & $\mathbf{0}$ & $\mathbf{0}$ & $\mathbf{0}$ & $\mathbf{0}$ & $\mathbf{1}$ & $\mathbf{1 0}$ & $\mathbf{0}$ \\
Tamarisk & $\mathbf{0}$ & $\mathbf{1}$ & $\mathbf{0}$ & $\mathbf{0}$ & $\mathbf{0}$ & $\mathbf{2}$ & $\mathbf{0}$ & $\mathbf{0}$ \\
Willow & $\mathbf{0}$ & $\mathbf{0}$ & $\mathbf{0}$ & $\mathbf{0}$ & $\mathbf{0}$ & $\mathbf{1 4}$ & $\mathbf{0}$ & $\mathbf{0}$
\end{tabular}

reported by Hughes, the exotic, tamarisk, was a major species on two of these drainages. The mid-1990's inventory showed the same results.

\section{The Vegetation Monitoring Methods}

The regeneration zone is that belt of young woody vegetation parallel to both river banks. The quantity and height class of each woody species was measured in three by six foot plots. A three hundred foot transect was designated in the regeneration zone. Plots were located at 10 foot intervals and each woody species was counted and placed in a height class. Height classes were 0-3 feet, 3-6 feet, 6-10 feet, and 10+feet. Usually one transect was placed on each side of the creek or river at the monitoring site). This was the Greenline Method as described in Cagney.

Typical weight based data were obtained from segment five of Kanab Creek. The 9.6 square foot circular plot was placed along a line ten times. At each plot vegetation was clipped and weighed. This data had three readings at different years (Interagency Technical Reference).

The monitoring was done on the Arizona segments on the above sites. Monitoring as described above began in 1991. Some monitoring sites have been read twice and others three times.

\section{Trend of the Regeneration Zones (See Figures 1-3) Virgin River}

Segment one, which is in the Gorge of the Virgin River in Arizona, showed an increase in willow from 1995 to 1998. Tamarisk also showed an increase of equal robustness. The cattle management of this segment permits grazing from January to May. Each pasture receives winter rest and spring rest every other year. Grazing does occur every other year in the spring when the willows are greening up. However, spring rest and light (20-40\%) to moderate (41-60\%) utilization levels on forage species during spring use years allows willows to be as aggressive as tamarisk and other woody shrubs. 

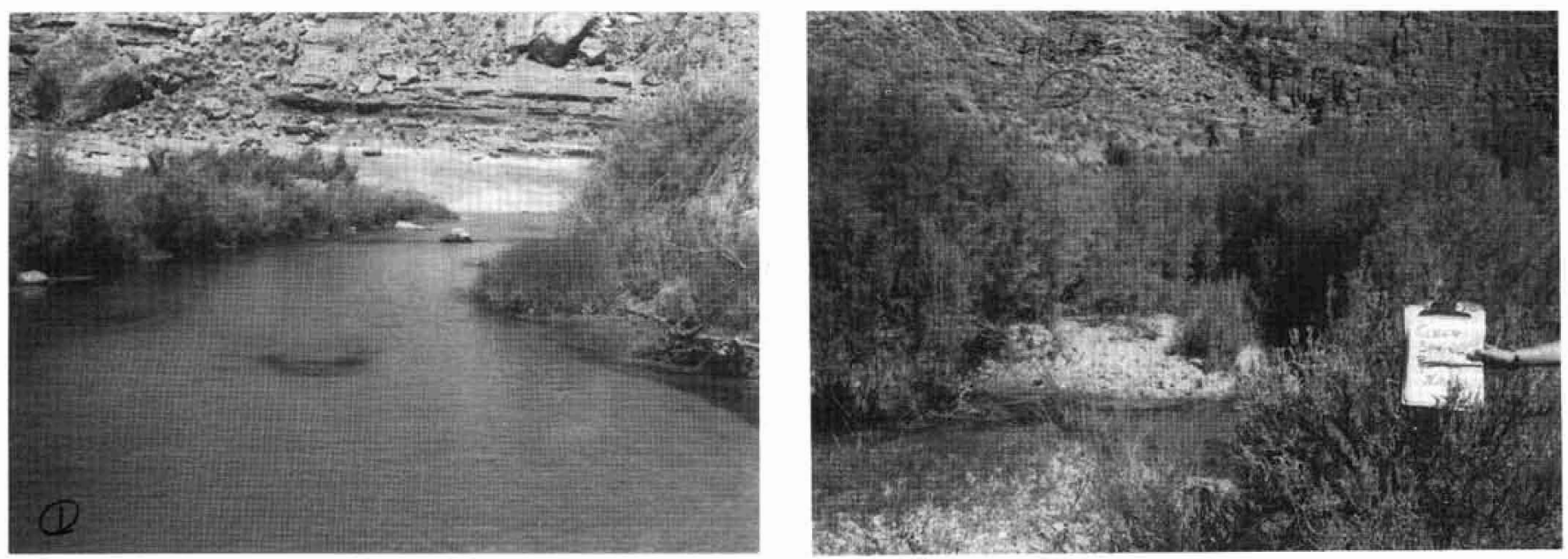

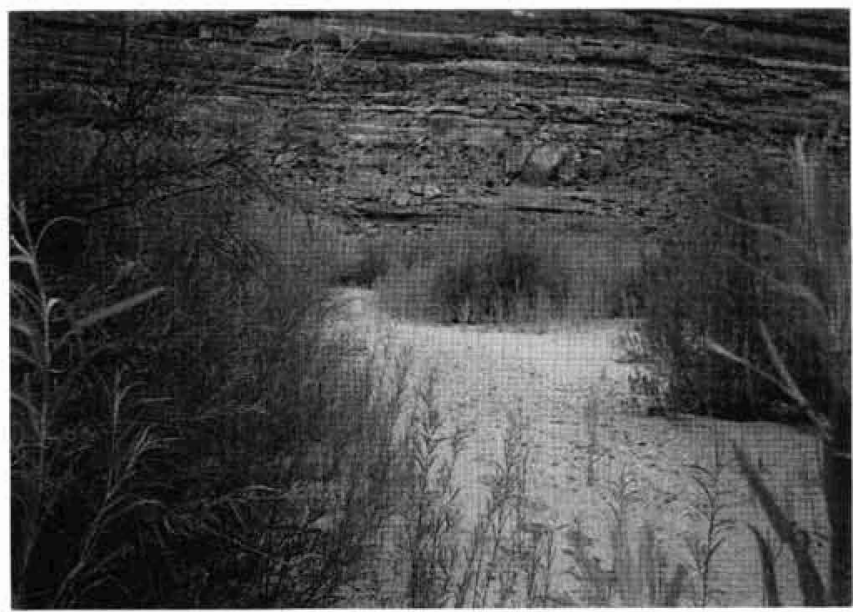

Fig. 1. Segment 1 transect area on the Virgin River. The top picture is from 1991 and the bottom picture is from 1998. Willow is a strong presence.

Segment seven of the Virgin River had a significant increase in the willow population over a two year period from 1996 to 1998. This segment is affected by a Category 1 habitat designation for desert tortoise, a threatened species. Cattle can

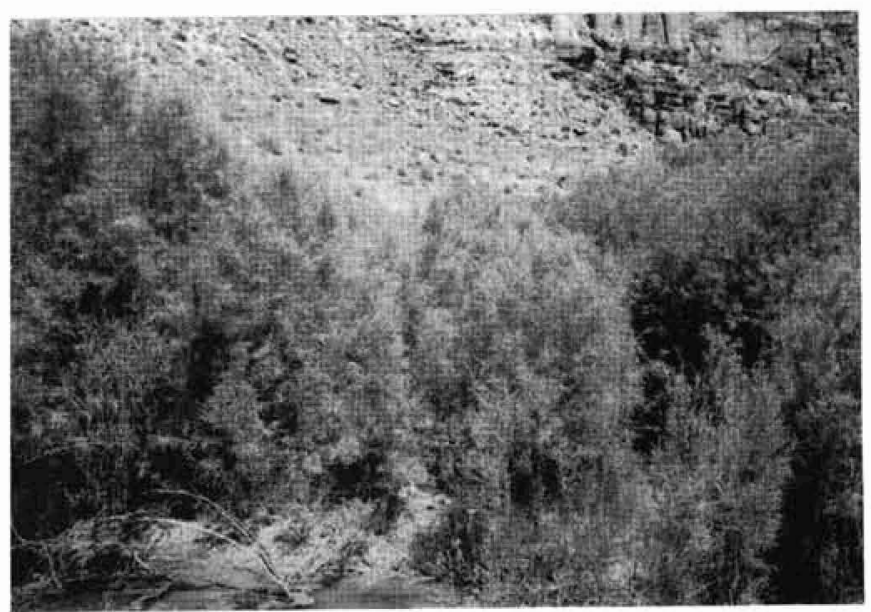

Fig. 2. Segment 3 on Kanab Creek transect area. Willows are on the increase. Top photo is from 1993 and bottom photo is from 1997.

graze the allotment in the winter; no livestock use had occurred in this segment from 1995 to 1998.

Segment nine is affected by Category 2 desert tortoise habitat designation (tortoise habitat and population are to be main-

TABLE 2

\begin{tabular}{llcl} 
& \multicolumn{2}{c}{ Kanab Creek } \\
& \multicolumn{1}{c}{$\begin{array}{c}\text { Weight } \\
\text { Data } \\
\text { Segment Five }\end{array}$} \\
\hline Tamarisk & 1991 & 1993 & 1997 \\
Rabbitbrush & 0 & $13 \%$ & $10 \%$ \\
Willow & 11 & 5 & 1 \\
Seep willow & 31 & 28 & 40 \\
Russian Olive & 0 & 6 & 10 \\
Salt Grass & 38 & 11 & 1 \\
Sedge & 8 & 34 & 12 \\
Other & 3 & Tr & 6 \\
\end{tabular}

Structure trend is not shown as there is only one reading and that was in 1997. 

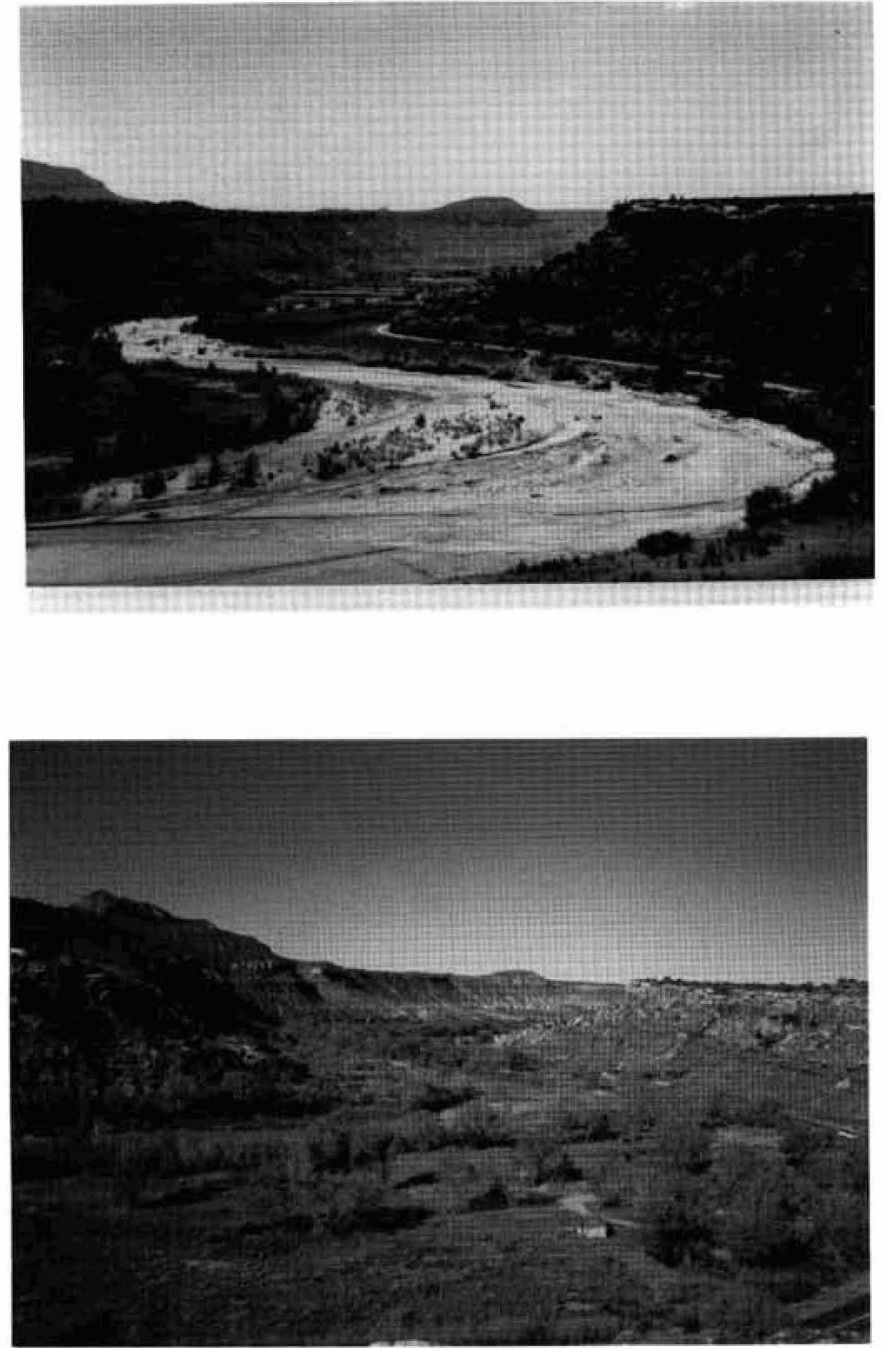

Fig. 3. Virgin River between Springdale and Rockville in Utah. Top photo from 1936 and bottom photo from 1996. Show narrowing of the river.

tained in stability) which, up to now has allowed for livestock use. Cattle grazing had occurred every winter and spring, but changed in 1999, when spring grazing ends. The trend of the willows and the tamarisk was down and the arrowweed increased almost ten fold from 1995 to 1998 . The location of the regeneration zone transect is now an upland site, as the river has moved $100+$ feet southward away from the transected zone, which is of higher elevation than the river. The transect was relocated in 1998 after the final trend reading.

\section{Kanab Creek}

Segment three of Kanab Creek showed a notable increase in the willow population in the regeneration zone. Little else exists in the zone. Willows in segment five of Kanab Creek showed a steady increase, the tamarisk had a static level, russian olive and seep willow went down in numbers, while rabbitrush maintained its presence. Thirty six head of cattle graze in the canyon from October through May each year.

\section{Paria River}

The trend transect in the lower segment of the Paria River showed small changes. Arrowweed and seep willow showed decreases, while cottonwood, russian olive, and willow showed increases. Tamarisk remained static. A week prior to monitoring the Paria site, a severe, high flood occurred, so the regeneration zones were mud caked at monitoring time. Normally, cattle grazing in the lower Paria occurs in the winter and spring with one year out of three as a rest-from-grazing year. However, no livestock grazing occurred in 1997 and 1998.

\section{Conclusion}

Tamarisk is an aggressive species but near the water zone in a riparian area several native species like willow, seep willow, and cottonwood can compete and increase their presence. Granted, observations of uplands above riparian zones show tamarisk can out compete plants (such as willow) when water is more distant. In the case of segment nine of the Virgin River the arrowweed, a native, increased in the drier floodplain rather than the tamarisk and willow, which were left high and dry by the river's relocation.

On the Arizona Strip when livestock are restricted to winter use and kept out of riparian areas during the growing seasons on a systematic basis, willows and other palatable woody species can grow and increase to their potential.

\section{Supporting Literature}

Cagney, Jim. 1993. Greenline Riparian-Wetland Monitoring Riparian Area Management TR 1737-8 1993. USDI-Bureau of Land Management, Denver, Colo.

DeLoach, C.J. 1997. Saltcedar and Biological Controls. The Arizona Riparian Council Newsletter 10(1):pp. 1\&3.

Hughes, Lee E. 1993. Tamarisk-The Devil's Own. Rangelands 15(4):151-155.

Interagency Technical Reference, 1996. Sampling Vegetation Attributes. BLM/RS/St-96/002+1730:pg 102-108.

Virgin River Basin Tamarisk Work Group Mission Statement. 1997.

The author is with the USDI-BLM in St. George, Utah. 